\title{
Sensitivity of soil nitrifying and denitrifying microorganisms to nitrogen deposition on the Qinghai-Tibetan plateau
}

\author{
Minjie Xur, ${ }^{1,2}$ Tingting $\mathrm{Li}^{2}$, Wei Liu², Junjun Ding ${ }^{2}$, Lili Gao ${ }^{2}$, Xingguo Han ${ }^{1 *}$ and Ximei Zhang ${ }^{2^{*}}$ (D)
}

\begin{abstract}
Purpose: Nitrogen deposition at rate not more than $50 \mathrm{~kg} \mathrm{ha}^{-1}$ year $^{-1}$ is generally considered to stimulate soil nitrifying and denitrifying microorganisms via increases in soil nitrogen content. However, this phenomenon in alpine ecosystems remains largely untested.
\end{abstract}

Methods: We conducted an 8-year nitrogen deposition experiment on the Qinghai-Tibetan Plateau, with four nitrogen deposition rates of 10 (atmospheric deposition), 20, 30, and $50 \mathrm{~kg} \mathrm{ha}^{-1}$ year $^{-1}$.

Results: The abundances of two nitrifying genes and four denitrifying genes and the $\mathrm{N}_{2} \mathrm{O}$ emission rate initially increased and subsequently decreased as the nitrogen deposition rate increased. The observed decrease in these indices at the rate of $50 \mathrm{~kg} \mathrm{ha}^{-1}$ year ${ }^{-1}$ was caused by the toxicity of excessive $\mathrm{NH}_{4}^{+}$.

Conclusions: Our study demonstrates the vulnerability of alpine microorganisms under global changes.

Keywords: Ammonium toxicity, Denitrification, $\mathrm{N}_{2} \mathrm{O}$, Nitrification, Nitrogen deposition, Qinghai-Tibetan plateau

Over the past few decades, environmental changes caused by anthropogenic activity, such as climate warming and nitrogen $(\mathrm{N})$ deposition, have played a large role in the disturbance of biological diversity and ecosystem functions (Klein et al. 2004; Chen et al. 2013). However, the effects of $\mathrm{N}$ deposition on soil microbial communities and their underlying mechanisms within the alpine area are yet to be fully understood. In many tropical and temperate ecosystems, $\mathrm{N}$ deposition at rate not more than $50 \mathrm{~kg} \mathrm{ha}^{-1}$ year $^{-1}$ stimulates the nitrification and denitrification of soil microbial communities by elevating the substrate contents of the two processes (Erickson et al. 2001; Baer and Blair 2008). N deposition at rate > $50 \mathrm{~kg} \mathrm{ha}^{-1}$ year $^{-1}$ often continues to stimulate the microbial nitrification process (Lehtovirta-Morley et al. 2011;

\footnotetext{
* Correspondence: xghan@ibcas.ac.cn; zhangximei@caas.cn

${ }^{1}$ State Key Laboratory of Vegetation and Environmental Change, Institute of Botany, Chinese Academy of Sciences, Beijing 100093, China

${ }^{2}$ Key Laboratory of Dryland Agriculture, Ministry of Agriculture, Institute of Environment and Sustainable Development in Agriculture, Chinese Academy of Agricultural Sciences, Beijing 100081, China
}

Zhang et al. 2012), yet depresses the microbial denitrification process (Gao et al. 2015). However, it is unclear whether the $\mathrm{N}$ deposition at rate not more than $50 \mathrm{~kg}$ $\mathrm{ha}^{-1}$ year $^{-1}$ will also stimulate microbial nitrification and denitrification in alpine ecosystems.

In this study, we conducted an 8-year (2007-2015) N addition experiment to simulate $\mathrm{N}$ deposition in a meadow ecosystem on the Qinghai-Tibetan Plateau, China (N 37 $37^{\prime}$, E $101^{\circ} 19^{\prime}$ ). The Qinghai-Tibetan Plateau has served as the roof of the world, the water tower of Asia, and the third pole of the Earth for 65 million years (Zheng et al. 1979; Wu and Yin 2002; Sun et al. 2012). The current $\mathrm{N}$ deposition rate at the Qinghai-Tibetan Plateau is recorded at approximately $10 \mathrm{~kg}$ $\mathrm{ha}^{-1}$ year $^{-1}$, with an increasing trend predicted for the next few decades ( $\mathrm{Lu}$ and Tian 2007). The vegetation type is a typical Kobresia humilis meadow. The soils developed in the Kobresia meadow are Mat-Gryic Cambisol (Fang et al. 2012). Four $\mathrm{N}$ addition rates were applied $\left(0,10,20\right.$, and $40 \mathrm{~kg} \mathrm{ha}^{-1}$ year $\left.^{-1}\right)$, and thus, the actual total $\mathrm{N}$ deposition rates (anthropogenically added

(c) The Author(s). 2021 Open Access This article is licensed under a Creative Commons Attribution 4.0 International License, which permits use, sharing, adaptation, distribution and reproduction in any medium or format, as long as you give

appropriate credit to the original author(s) and the source, provide a link to the Creative Commons licence, and indicate if changes were made. The images or other third party material in this article are included in the article's Creative Commons licence, unless indicated otherwise in a credit line to the material. If material is not included in the article's Creative Commons licence and your intended use is not permitted by statutory regulation or exceeds the permitted use, you will need to obtain permission directly from the copyright holder. To view a copy of this licence, visit http://creativecommons.org/licenses/by/4.0/. 
rate + naturally deposited rate) were approximately 10 , 20,30 , and $50 \mathrm{~kg} \mathrm{ha}^{-1} \mathrm{year}^{-1}$, respectively. Two types of nitrogenous compounds, $\mathrm{NH}_{4} \mathrm{Cl}$ and $\mathrm{KNO}_{3}$, were added for each of the latter three rates. Thus, there were seven treatments, with three replicates (in three blocks) for each treatment. In 2015, the abundances of two nitrifying (AOA-amoA and $\mathrm{AOB}-a m o A)$ and four denitrifying genes (nirS, nirK, narG, and nosZ) of soil microbial communities were quantified using real-time PCR analysis. The $\mathrm{N}_{2} \mathrm{O}$ emission rate was quantified in situ via gas
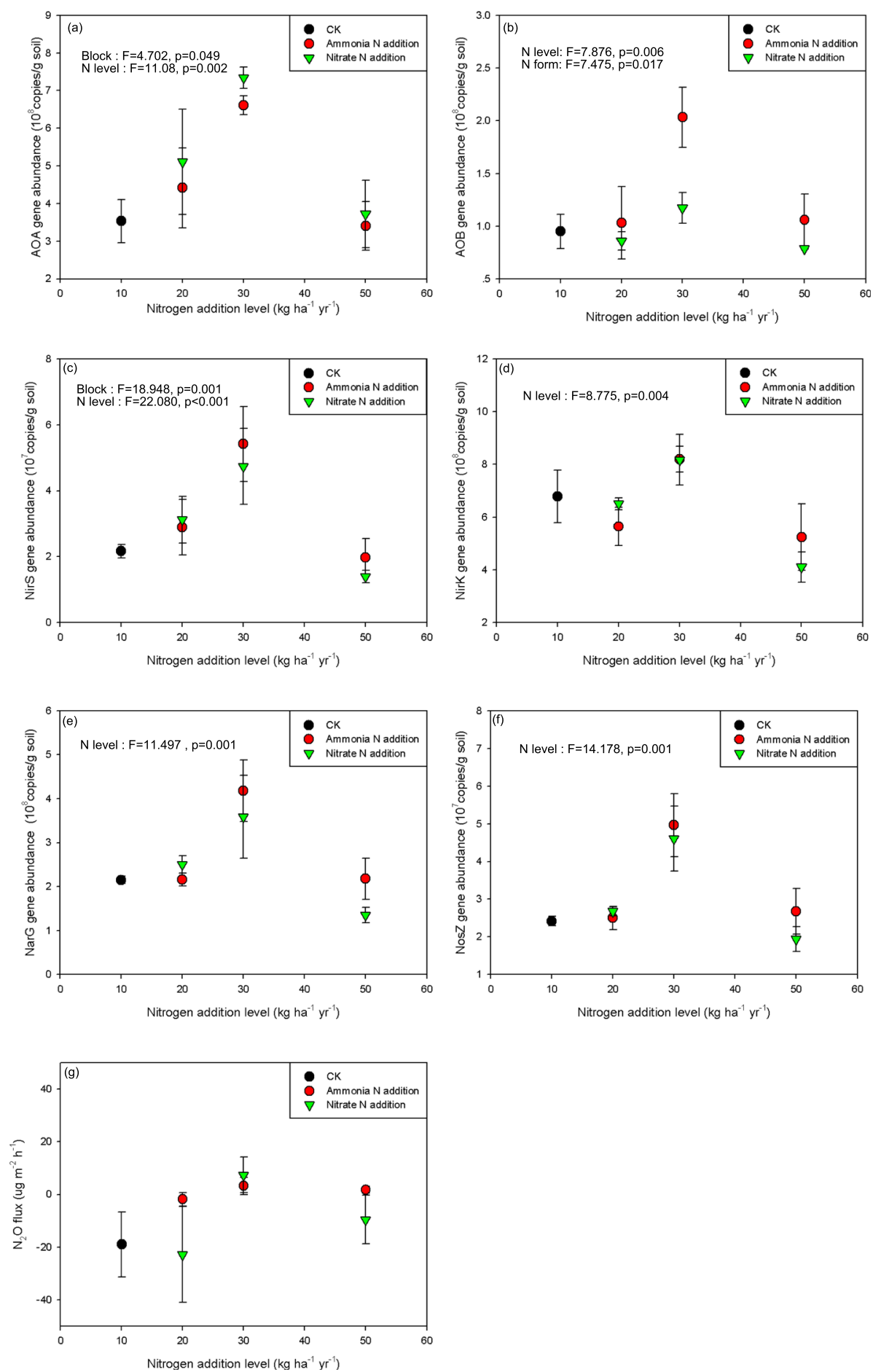

Fig. 1 Relationship between community size of $\mathbf{a}$, $\mathbf{b}$ nitrifying and $\mathbf{c}-\mathbf{f}$ denitrifying microorganisms, $\mathbf{g ~ N} \mathrm{N}_{2} \mathrm{O}$ emission rate, and nitrogen deposition rate. Error bars represent one standard error 
chromatography (Wang and Wang 2003). In addition, plant community biomass and soil physicochemical indices (soil water content, $\mathrm{pH}$, dissolved organic carbon content, $\mathrm{NO}_{3}{ }^{-}-\mathrm{N}$ content, and $\mathrm{NH}_{4}{ }^{+}-\mathrm{N}$ content) were also measured (see Method S1).

The abundances of the two nitrifying and four denitrifying genes initially increased and subsequently decreased as the $\mathrm{N}$ deposition rate increased, with maximum values associated with $30 \mathrm{~kg} \mathrm{ha}^{-1}$ year $^{-1}$ (Fig. 1a-f). The $\mathrm{N}_{2} \mathrm{O}$ emission rate exhibited a similar trend as that of the gene abundances, especially for the treatments of $\mathrm{KNO}_{3}$ addition (Fig. 1g). Specifically, an increase in the $\mathrm{N}$ deposition rate from 10 to $30 \mathrm{~kg} \mathrm{ha}^{-1}$ year $^{-1}$ resulted in a rise in the gene abundances and $\mathrm{N}_{2} \mathrm{O}$ emission rate due to elevated soil $\mathrm{N}$ content. This is consistent with tropical and temperate ecosystems (Xie et al. 2018; Zhang et al. 2018). However, further increases in the $\mathrm{N}$ deposition rate (from
30 to $50 \mathrm{~kg} \mathrm{ha}^{-1}$ year $^{-1}$ ) led to a decline in the index values, differing from results in the literature (Frey et al. 2004; Tian et al. 2014; Zeng et al. 2016).

This unexpected decline in the indices was not attributed to aboveground plant biomass, soil water content, and dissolved organic carbon content, as these variables responded non-significantly to the $\mathrm{N}$ deposition rate, as revealed by a two-way analysis of variance (Fig. 2a, c-d). Furthermore, as the $\mathrm{N}$ deposition rate increased from 30 to $50 \mathrm{~kg} \mathrm{ha}^{-1} \mathrm{year}^{-1}$, no consistent changes were observed for soil $\mathrm{pH}$ under the addition of $\mathrm{NH}_{4} \mathrm{Cl}$ and $\mathrm{KNO}_{3}$ (Fig. 2b). Specifically, soil pH levels decreased with the addition of $\mathrm{NH}_{4} \mathrm{Cl}$, yet remained constant with the addition of $\mathrm{KNO}_{3}$. Thus, soil pH was not an influencing factor for the observed decline in the seven indices. Similarly, soil $\mathrm{NO}_{3}{ }^{-}-\mathrm{N}$ content remained unchanged under the addition of both $\mathrm{NH}_{4} \mathrm{Cl}$ and $\mathrm{KNO}_{3}$ (Fig. 2e).
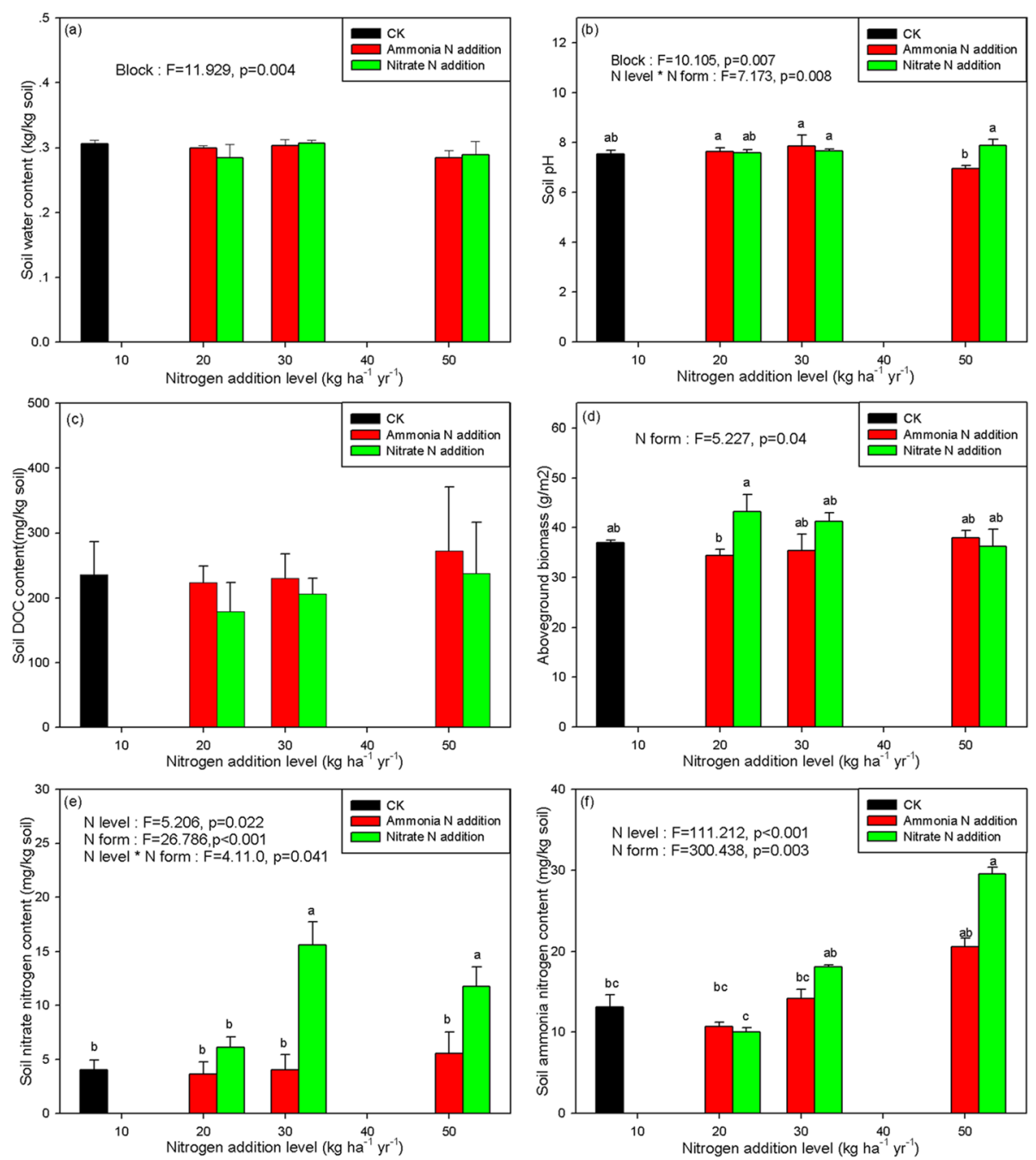

Fig. 2 Effects of $\mathrm{N}$ deposition rate on a soil water content, b soil $\mathrm{pH}$, $\mathbf{c}$ dissolved organic carbon content, $\mathbf{d}$ aboveground plant biomass, e soil $\mathrm{NO}_{3}{ }^{-}-\mathrm{N}$ content, and $\mathbf{f} \mathrm{NH}_{4}{ }^{+}-\mathrm{N}$ content. Error bars represent one standard error. For clarity, the statistical results with $P>0.05$ are not shown 
In contrast, soil $\mathrm{NH}_{4}{ }^{+}-\mathrm{N}$ content increased consistently with the rise in nitrogen deposition under the addition of both $\mathrm{NH}_{4} \mathrm{Cl}$ and $\mathrm{KNO}_{3}$ (Fig. 2f) and is thus identified as a likely cause of the reduced index values.

Excessive soil $\mathrm{NH}_{4}{ }^{+}$concentrations are able to change the ion balance in plants through their uptake of cations and thus are toxic to plants (Britto and Kronzucker 2002; Esteban et al. 2016). Moreover, soil microorganisms are considered to be less resistant to environmental pressures compared to higher plants (Zhang et al. 2015; Zhang et al. 2016). Hence, the excessive $\mathrm{NH}_{4}{ }^{+}$concentration under the nitrogen deposition rate of $50 \mathrm{~kg} \mathrm{ha}^{-1}$ year $^{-1}$ is likely to be toxic to soil microorganisms, leading to the observed decline in the seven indices (Fig. 1). Note the addition of $\mathrm{NO}_{3}^{-}-\mathrm{N}$ (in the form of $\mathrm{KNO}_{3}$ ) from 30 to $50 \mathrm{~kg} \mathrm{ha}^{-1}$ year $^{-1}$ was associated with a slight reduction in soil $\mathrm{NO}_{3}{ }^{-}-\mathrm{N}$ content, while $\mathrm{NH}_{4}{ }^{+}-\mathrm{N}$ content slightly increased (Fig. 2e, f). This implies that a large amount of $\mathrm{NO}_{3}{ }^{-}-\mathrm{N}$ was transformed into $\mathrm{NH}_{4}{ }^{+}-\mathrm{N}$, possibly driven by plants and/or microorganisms (Esteban et al. 2016). Both the transformation of $\mathrm{NO}_{3}{ }^{-} \mathrm{N}$ to $\mathrm{NH}_{4}{ }^{+}-\mathrm{N}$ and the toxicity of excessive $\mathrm{NH}_{4}{ }^{+}$for microorganisms require further exploration to fully understand the mechanisms.

In summary, $\mathrm{N}$ deposition at rate not more than $50 \mathrm{~kg}$ $\mathrm{ha}^{-1} \mathrm{year}^{-1}$ may either stimulate nitrifying and denitrifying microorganisms through increases in soil $\mathrm{N}$ content or depress these microorganisms via $\mathrm{NH}_{4}{ }^{+}$toxicity. In some tropical and temperate ecosystems, many microorganisms are resistant to $\mathrm{NH}_{4}{ }^{+}$toxicity, thus exhibiting a net positive response to low deposition rates (Ning et al. 2015; Tian et al. 2018). In contrast, microorganisms found in alpine ecosystems do not present such a resistance to $\mathrm{NH}_{4}{ }^{+}$ toxicity, highlighting the vulnerability of microorganisms in such unique ecosystems. Moreover, for other types of ecosystems, $\mathrm{N}$ deposition is observed to have a cumulative effect (Dupre et al. 2010). Thus, it is also important to identify whether $\mathrm{N}$ deposition rates at rate not more than $30 \mathrm{~kg} \mathrm{ha}^{-1}$ year $^{-1}$ can cause a net negative effect on microorganisms for longer treatments. A further key point is to determine whether the relationship observed on the Qinghai-Tibetan Plateau between the community size of nitrifying and denitrifying microorganisms and nitrogen deposition at rate not more than $50 \mathrm{~kg} \mathrm{ha}^{-1}$ year $^{-1}$ also applies to other alpine ecosystems in the world.

\section{Supplementary Information}

The online version contains supplementary material available at https://doi. org/10.1186/s13213-020-01619-z.

Additional file 1: Methods

\section{Authors' contributions}

MX designed the research, carried out the experiment, and drafted the manuscript. XZ improved the writing of the manuscript. All authors have read and approved the final manuscript.

\section{Funding}

This research was supported by the National Key Research and Development Program (2016YFC0500702) and the China Major Science and Technology Program for Water Pollution Control and Treatment (2017ZX07101003).

\section{Availability of data and materials}

All data analyzed during this study are included in this published article and its supplementary information files.

Ethics approval and consent to participate

Not applicable.

Consent for publication

Not applicable.

\section{Competing interests}

The authors declare that there is no competing interest.

Received: 1 December 2020 Accepted: 28 December 2020

Published online: 22 January 2021

\section{References}

Baer SG, Blair JM (2008) Grassland establishment under varying resource availability: a test of positive and negative feedback. Ecology 89:1859-1871

Britto DT, Kronzucker HJ (2002) NH4+ toxicity in higher plants: a critical review. J Plant Physiol 159:567-584

Chen $\mathrm{H}$, Zhu QA, Peng CH, Wu N, Wang YF, Fang XQ, Gao YH, Zhu D, Yang G, Tian JQ, Kang XM, Piao SL, Ouyang H, Xiang WH, Luo ZB, Jiang H, Song XZ, Zhang Y, YU GR, Zhao XQ, Gong P, Yao TD, Wu JH (2013) The impacts of climate change and human activities on biogeochemical cycles on the Qinghai-Tibetan plateau. Glob Chang Biol 19:2940-2955

Dupre C, Stevens CJ, Ranke T, Bleeker A, Peppler-Lisbach C, Gowing DJG, Dise NB, Dorland E, Bobbink R, Diekmann M (2010) Changes in species richness and composition in European acidic grasslands over the past 70 years: the contribution of cumulative atmospheric nitrogen deposition. Glob Chang Biol 16:344-357

Erickson H, Keller M, Davidson EA (2001) Nitrogen oxide fluxes and nitrogen cycling during postagricultural succession and forest fertilization in the humid tropics. Ecosystems 4:67-84

Esteban R, Ariz I, Cruz C, Moran JF (2016) Review: mechanisms of ammonium toxicity and the quest for tolerance. Plant Sci 248:92-101

Fang HJ, Cheng SL, Yu GR, Zheng JJ, Zhang PL, Xu MJ, Li YN, Yang XM (2012) Responses of $\mathrm{CO}_{2}$ efflux from an alpine meadow soil on the Qinghai Tibetan plateau to multi-form and low-level N addition. Plant and Soil 351:177-190

Frey SD, Knorr M, Parrent JL, Simpson RT (2004) Chronic nitrogen enrichment affects the structure and function of the soil microbial community in temperate hardwood and pine forests. Forest Ecol Manag 196:159-171

Gao WL, Yang H, Kou L, Li SG (2015) Effects of nitrogen deposition and fertilization on $\mathrm{N}$ transformations in forest soils: a review. J Soil Sediment 15: 863-879

Klein JA, Harte J, Zhao XQ (2004) Experimental warming causes large and rapid species loss, dampened by simulated grazing, on the Tibetan plateau. Ecol Lett 7:1170-1179

Lehtovirta-Morley LE, Stoecker K, Vilcinskas A, Prosser Jl, Nicol GW (2011) Cultivation of an obligate acidophilic ammonia oxidizer from a nitrifying acid soil. P Natl Acad Sci USA 108:15892-15897

Lu CQ, Tian HQ (2007) Spatial and temporal patterns of nitrogen deposition in China: synthesis of observational data. J Geophys Res 112, D22S05. https:// doi.org/10.1029/2006JD007990

Ning QS, Gu Q, Shen JP, Lv XT, Yang JJ, Zhang XM, He JZ, Huang JH, Wang $H$, Xu $Z H, H a n X G$ (2015) Effects of nitrogen deposition rates and frequencies on the abundance of soil nitrogen-related functional genes in temperate grassland of northern China. J Soil Sediment 15:694-704

Sun H, Zheng D, Yao T, Zhang Y (2012) Protection and construction of the national ecological security shelter zone on Tibetan plateau. Acta Geograph Sin 67:3-12 Chinese with English abstract 
Tian D, Du EZ, Jiang L, Ma SH, Zeng WJ, Zou AL, Feng CY, Xu LC, Xing AJ, Wang W, Zheng CY, Ji CJ, Shen HH, Fang JY (2018) Responses of forest ecosystems to increasing $N$ deposition in China: a critical review. Environ Pollut 243:75-86

Tian XF, Hu HW, Ding Q, Song MH, Xu XL, Zheng Y, Guo LD (2014) Influence of nitrogen fertilization on soil ammonia oxidizer and denitrifier abundance, microbial biomass, and enzyme activities in an alpine meadow. Biol Fertil Soils 50:703-713

Wang YS, Wang $\mathrm{YH}$ (2003) Quick measurement of $\mathrm{CH}_{4}, \mathrm{CO}_{2}$ and $\mathrm{N}_{2} \mathrm{O}$ emissions from a short-plant ecosystem. Adv Atmos Sci 20:842-844

Wu SH, Yin YH (2002) Climatic trends over the Tibetan plateau during 1971-2000. In: The editorial Committee of the eco-environment of nature reserves in the three Rivers' source region (ECENRTR) (Eds), the eco-environment of nature reserves in the three Rivers' source. Qinghai People's Press, Xining, pp 179-180

Xie DN, Si GY, Zhang T, Mulder J, Duan L (2018) Nitrogen deposition increases $\mathrm{N}_{2} \mathrm{O}$ emission from an $\mathrm{N}$-saturated subtropical forest in Southwest China. Environ Pollut 243:1818-1824

Zeng J, Liu XJ, Song L, Lin XG, Zhang HY, Shen CC, Chu HY (2016) Nitrogen fertilization directly affects soil bacterial diversity and indirectly affects bacterial community composition. Soil Biol Biochem 92:41-49

Zhang LM, Hu HW, Shen JP, He JZ (2012) Ammonia-oxidizing archaea have more important role than ammonia-oxidizing bacteria in ammonia oxidation of strongly acidic soils. ISME J 6:1032-1045

Zhang TA, Chen HYH, Ruan HH (2018) Global negative effects of nitrogen deposition on soil microbes. ISME J 12:1817-1825

Zhang XM, Johnston ER, Liu W, Li LH, Han XG (2016) Environmental changes affect the assembly of soil bacterial community primarily by mediating stochastic processes. Glob Chang Biol 22:198-207

Zhang XM, Liu W, Zhang GM, Jiang L, Han XG (2015) Mechanisms of soil acidification reducing bacterial diversity. Soil Biol Biochem 81:275-28

Zheng D, Zhang R, Yang Q (1979) On the natural zonation in the Qinghai-Xizang plateau. Acta Geograph Sin 1-11(Chinese with English abstract):34

\section{Publisher's Note}

Springer Nature remains neutral with regard to jurisdictional claims in published maps and institutional affiliations.

Ready to submit your research? Choose BMC and benefit from:

- fast, convenient online submission

- thorough peer review by experienced researchers in your field

- rapid publication on acceptance

- support for research data, including large and complex data types

- gold Open Access which fosters wider collaboration and increased citations

- maximum visibility for your research: over $100 \mathrm{M}$ website views per year

At $\mathrm{BMC}$, research is always in progress.

Learn more biomedcentral.com/submissions 